\title{
Legal Framework of Racial Discrimination
}

\section{Hassan Zia Muhammad*}

Department Of Law, University of Punjab, Gujranwala Campus, Pakistan

*Corresponding author: Muhammad HZ, Department Of Law, University of Punjab, Gujranwala Campus, Pakistan, Tel: 03225701810; E-mail: hasanzia489@hotmail.com

Received date: July 06, 2017; Accepted date: July 24, 2017; Published date: July 28, 2017

Copyright: (C) 2017 Muhammad HZ. This is an open-access article distributed under the terms of the Creative Commons Attribution License, which permits unrestricted use, distribution, and reproduction in any medium, provided the original author and source are credited.

\section{Abstract}

In the progressive era of 21st Century where everyone agrees upon racial discrimination being a menace, this topic demands still demands attention from every responsible individual as inequity continues. This paper deals with the laws enacted to prevent racial discrimination in UK. Different instruments of law i.e, ICCPR and ECHR are elaborated in the paper. The aim is to analyze the efficacy of these laws and to scrutinize them to minimize the racial discrimination.

Keywords: Racial discrimination; Human rights; Discrimination; Communists regimes

\section{Introduction}

\section{Racial discrimination means}

To treat differently a person or group of people based on their racial origins. Power is a necessary precondition, for it depends on the ability to give or withhold social benefits, facilities, services, opportunities etc., from someone who should be entitled to them, and are denied on the basis of race, color or national origin ${ }^{1}$.

Realizing the ever growing importance of the subject of race discrimination researcher here would critically analyze the prospects of the unprejudiced approach. This shall be done by explaining all human rights instruments that deal with race discrimination, Art 26 of ICCPR, and Art 14 of ECHR. It is anticipated that very framework meant to curtail inequity might not be endorsing it inadvertently. After briefly describing the general outlook of the topic the researcher would elaborate upon the legal framework and existing loopholes.

Such discrimination appears illegal and immoral under the fact that God has created this world and all human beings of every colour, race, sex, etc. Any distinction on the basis of such traits should not hold its place in a pure heart. Confining particular class of people or group within certain boundaries would be unethical. For this reason Human rights approach took its place.

Human rights are international norms that help to protect all people everywhere from severe political, legal, and social abuses. Examples of human rights are the right to freedom of religion, the right to a fair trial when charged with a crime, the right not to be tortured, and the right to engage in political activity. These rights exist in morality and in law at the national and international levels ${ }^{2}$.

Various actions have been taken under human rights approach in the history. Reform Act 1832 might be referred to be among the pioneer steps taken in the Uk for human rights, and then various international organizations came to existence specially in the aftermath effects of the World War II. Among these organizations the United Nations, the Council of Europe, the Organization of American States, and the African Union are worth mentioning. Desire to have peaceful co-existence, harmony and liberty has led the foundation of certain principles of Human Rights. For instance Article 1 of the Universal Declaration of Human Rights 1948 states that, "All human beings are born free and equal in dignity and rights. They are endowed with reason and conscience and should act towards one another in a spirit of brotherhood."

None would argue on the Race discrimination being a vice that has to be eradicated from the society. Various methods, i.e. promoting equality, identifying root causes, and educating the masses etc., can prove beneficial in wiping off this evil from the face of the earth. The survey by EC commissioned conducted in year 1997, European year against Racism, shows that fear of losing jobs is the largest factor in determining racist attitudes. The hopeful aspect of this survey was that $86 \%$ of people oppose "any discrimination on the grounds of person's race, religion and culture" [1].

\section{International and regional instruments}

The major international instruments that deal with discrimination and equality are

- the International covenant on civil and political rights ("ICCPR");

- the International Covenant on Economic, Social and Cultural Rights ("ICESCR"),

- the International Convention on the Elimination of all Forms of Racial Discrimination ("CERD");

- the Convention on the Elimination of all Forms of Discrimination against Women ("CEDAW") and

- The Convention on the Rights of the Child (“CRC”).

In addition to these conventions there are regional treaties that discourage discrimination and promote equality such as the African Charter on Human and People's Rights, the European Social Charter

The ideology of racism qtd in academia website in "RACE, RACISM AND THE LAW" np.

2 stanford encyclopedia of philosophy np 
Page 2 of 5

of 1961 and revised Social Charter of 1996, and European Union Charter of Fundamental Rights, the American Convention on Human Rights ,the European Convention on Human Rights, the Arab Charter on Human Rights adopted by the Council of the League of Arab States in 1994, has yet to be ratified by the Member States of the League.

Human rights instruments deal with the evil of discrimination differently. However, the ICCPR, ICESCR and African Charter contain similar provisions against discrimination. (Art.2 of ICESCR and of African Charter is similar to Art 2 of ICCPR).

American and European Convention do not contain any independent provisions against discrimination. McColgan argues that though these provisions (American Convention (Art 1) and European Convention (art 14)) create positive obligations on government to protect from discrimination but the degree of obligation is not clear. Moreover, the problem of discrimination by private parties is not properly addressed by these provisions [2]. To activate these provisions, having 'parasitic' nature, it is necessary that discriminatory arguments fall within the ambit of substantive rights mentioned in the conventions.

Positive discrimination is permitted by almost all human rights instruments. For instance, Human Rights Committee in its general comment no 18 stated:

The enjoyment of rights and freedoms on an equal footing does not mean identical treatment in every instance. In this connection, the provisions of the Covenant are explicit. For example, article 6, paragraph 5, prohibits the death sentence from being imposed on persons below 18 years of age. The same paragraph prohibits that sentence from being carried out on pregnant women. Similarly, article 10 , paragraph 3 , requires the segregation of juvenile offenders from adults. Furthermore, article 25 guarantees certain political rights, differentiating on grounds of citizenship.

Both CERD and CEDAW have made it clear that positive discrimination is allowed to guarantee substantive equality. Art 1 (4) of CERD and Art 4 of CEDAW can explain it further. Preferential treatment can be given to particular class or group who had been neglected, to attain de facto equality. This preferential treatment is necessary to eliminate conditions that promote discrimination prohibited in the covenants. But this preferential treatment should be within the legitimate means and this treatment should be stopped after achieving objectives.

CERD and CEDAW also discourage discrimination on every level and on any ground. For instance Art 5 of CERD not only discourages discrimination in any form but also promotes a right to equality of 'everyone' without any distinction in equal treatment of law, protection against violence whether inflicted by government officials or by group of individuals and protection of civil rights and political rights. CEDAW also puts obligations on state parties to eradicate discrimination against women. For instance Art 7 and 8, promote participation of women in the political and public life of the country. In addition to this article, CEDAW also condemn discrimination against women in social (Art 16) and legal fields (Art 15).

Many equality provisions in various human rights instruments put obligations on states to protect individuals from discrimination by private parties. For instance, Art 5 (b) and Art 2 of CERD. Art 2 of CEDAW provides that states should promote equality between men and women but also make sure through law and other means a 'practical realization' of this equality. Art 15 and Art 18(3) of African
Charter also condemn discrimination. Art 15, promote right of everyone "to equal pay for equal work" and Art 18(3) not only discourages discrimination but also ensures the protection of women and child rights as mentioned in international conventions. Art 7 of ICESCR states that, to the enjoyment of just and favorable conditions of work in particular fair wages and equal remuneration for work of equal value without distinction of any kind, in particular women being guaranteed conditions of work not inferior to those enjoyed by men, with equal pay for equal work [and] equal opportunity for everyone to be promoted in his employment to an appropriate higher level, subject to no considerations other than those of seniority and competence.

Thus covering a wide scope this approach provides rights to everyone from a child to an adult. Educating the mob that is still caught in discrimination is another purpose.

\section{The International Covenant on Civil and Political Rights (ICCPR)}

This covenant was formulated in 1966 and came in force in 1976. The purpose of this convention is to give legal status to civil and political rights and fundamental freedoms that are contained in the Universal Declaration of Human Rights (UDHR). The importance given by the international law to the principle of equality is clear by the article 26 of this covenant and affirmative equality provisions in ICERD and CEDAW. The UN has also developed 'soft laws' to give guidelines to state parties in eradications of all forms of discrimination (e.g. Declaration on the Elimination of All Forms of Intolerance and of Discrimination Based on Religion or Belief 1981) [1]

The ICCPR encourages the principle of the equality. Article 2(1) elaborates that the rights in the covenant are promised without discrimination. Article 3 deals with equal rights of man and woman in enjoyment of all rights of covenant. Article 14(1) provides equality before the courts and Article 23(4) deals with equal rights of spouses. Articles 6(1), 9(1) and 12(4) deals with arbitrary matters. Equality and non-discrimination are two issues that have been discussed throughout this covenant.

In fact, this covenant deals with every form of discrimination on any ground very strictly. The Human Rights committee HRC ('the committee') is responsible for the implementation of the ICCPR. The committee's jurisprudence is very helpful in the interpretation of equality right as human right.

The most important article of this covenant that deals with discrimination is Article 26, which states.

All persons are equal before the law and are entitled without discrimination to the equal protection of the law. In this respect, the law shall prohibit discrimination and guarantee to all persons equal and effective protection against discrimination on any grounds such as race, colour, sex, language, religion, political or other opinion, national or social origin, property birth or other status.

Article 26 is an autonomous article and is not ancillary to any article in covenant or any other right in international treaties. As compared to article 14 of ECHR the scope of this article is not limited to its covenant rights. Article 26 has three parts that all persons are

- Equal before law

- Entitled for the equal protection of the law

- Equal and effective protection against every kind of discrimination on any ground. 
General comment 18 says about justification of treatment.

"Not every differentiation of treatment will constitute discrimination, if the criteria for such differentiation are reasonable and objective and if the aim is to achieve a purpose which is legitimate under the Covenant" [3].

It means that distinction should be objective, reasonable and in the pursuance of the legitimate aim.

The scope of article 26 was set in Broeks v the Netherlands (172/1984) decision by the committee-that its scope was extended to all types of rights in other international treaties, including social security rights in ICESCR. The Broeks decision was confirmed in General comment 18, the committee says,

"Application of principle of non-discrimination contained in Art 26 is not limited to those rights which are provided for in the covenant". It means that scope of Art 26 covers all the rights that are mentioned in other international human rights instruments.

The committee also addresses the claims that relates to Restitution of property expropriate under communists regimes in the Eastern Europe (Diergaardt v Namibia 760/1997; Drobek v Slovakia 643/1995).

The remarkable achievement of the committee is that it extends the scope of article 26 to criminal justice matters. In Grots v Netherlands (578/1994) the complainant alleged a breach of right to equality before the law. The committee found the communication inadmissible as the fact in this case revealed no evidence of deliberate policy of unequal treatment. The availability of article 28 to deal with criminal matters was confirmed in Kavanagh v Ireland (819/1998). However, in this case the committee concluded that the Ireland has failed to give any objective and reasonable grounds for trying Joseph in special Criminal Courts. Under Irish law only those persons were tried in "SCC" when normal courts were "inadequate to secure the effective administration of justice in relation to the trial of such person".

Article 26 condemns both direct and indirect discrimination and also extends its scope to protect against horizontal effects of discrimination. In the Third Committee of the General Assembly, it was made clear that state are bound because of article 26 to stop discrimination among private parties in quasi-public sectors of employment, schools, transportation, hotels, restaurants, theatres etc. It means that when people of particular class or group are consistently refrained to enjoy rights in private restaurants, theatres, beaches, the state is under an obligation to take necessary steps to stop this discrimination (M Nowak, 'The International Covenant on Civil and Political rights, The Hague, 1993, p 478) [1]. The committee for the Elimination of the Racial Discrimination (CERD) has made clear that they are competent enough to deal with questions of private discrimination (Yilmax Dogan $\mathrm{v}$ The Netherlands CERD Communication no 1/1984).

The HRC has not held every distinction as discrimination. The committee's definition of distinction in General comment 18 is;

... any distinction, exclusion, restriction or preference which is based on any ground such as race, colour, sex, language, religion, political or other opinion, national or social origin, property, birth or other status, and which has the purpose or effect of nullifying or impairing the recognition, enjoyment or exercise by all persons, on an equal footing, of all rights and freedoms.

Article 26 contains an open list of prohibited grounds of discrimination. The phrase 'other status' covers, nationality, marital status, a distinction between 'foster' and 'natural' children and a difference in funding between public and private schools. The last distinction has further extended the scope of the article 26 as it does not define any personal characteristics of the complainant. The committee has not defined any particular criterion which decides that whether particular treatment comes within the category of 'other status' or not. It lacks clarity.

Another amazing success of the committee is that homosexuals are covered by reference 'sex' in the article and are protected from any form of discrimination (Toonen V Australia CCPR/C/50/D/488/1992).

The committee's jurisprudence in case of indirect discrimination is very weak, especially to the rules relating to access of social security payments [3].

In the beginning the committee says "Differences in result from the uniform application of laws do not per se constitute prohibited discrimination." Later on committee removed the word' per se 'and made definite rule.

"The scope of Art 26 of the Covenant does not extend to differences resulting from the equal application of a rule in the allocation of benefits".

It means that to prove claim complainant has to prove that there is no equal application of rule of law in the allocation of the benefits. The committee's approach in JAMB-R v Netherlands (477/1991) is confusing. The complainant, a female teacher was unemployed from August 1983 to August 1985. For the first six months of her unemployment she received benefits under Unemployment Act. From February 1984 she was authorized to apply for benefit of further two years. She made an application in 1985 but her application was rejected on the ground that she was not a bread winner. Accordingly, to s.13 of Unemployment Provision Act, married woman can only receive payments if she is bread winner. This criterion applies only to woman. However, committee found this criterion discriminatory against women in Broek's communication. In 1985, Netherland removed this criterion of bread winner. In 1991, the Unemployment Benefits Act was amended and allowed for claims dating back in December 1984, but to qualify for the back payments applicant should be unemployed at the time when applicant applies. The complainant was fully employed in 1991 and she failed to apply. The committee did not find any discrimination as rule applies equally to man and woman. But, the criterion of bread winner applies only to married woman not to married man. So, in practice the new rule of unemployed applicant applies only to woman. The committee's approach was criticized on the ground that it focuses more on the equality of rule between employed and unemployed people rather than protecting woman from the adverse effects of bread winner criterion.

This criticism is appears valid as a bread winner criterion affected woman more than man, this fact was ignored by the committee and also retroactive compensation was paid on the criterion of employed and unemployed basis. Similar approach was taken by the committee in the Araujo-Jongen v Netherlands (418/1990).

In another case of Oulajin and Kasis (406,426/1990), the complainants were migrant's workers from Morocco and working in Netherland. They claimed that the rules of foster children were indirectly discriminated against migrant workers as Dutch parents are more likely to have foster children. Their claim was rejected on the ground that complainant failed to show a close link with their foster children. The Netherlands argued that there is no evidence to prove 
that these rules are discriminatory. Netherland has interpreted committee jurisprudence in a manner so that indirect discrimination could not apply in social security systems. Committee does not take notice of this interpretation rather it blames complainants since they failed to prove their substantiate claims of indirect discrimination.

The committee is not giving the due importance to indirect discrimination cases and letting the evil to grow. The committee should handle the matters of indirect discrimination strictly, as definition of discrimination in General comment 18 covers both intended and unintended discrimination. The cases that are mentioned above involve indirect discrimination, something more than mere intention.

Another weakness refers to committee's limited power to remind states that they are under an obligation to provide an effective remedy. The optional protocol lacks the ability to ask question from states parties, that what they have done to give effect to committee views. However, according to Art 2 (3) of the covenant a report should be submitted by the state parties explaining the steps taken to remedy the complainant. Since 1990, the committee has appointed a special Rapporteur who monitors the state party's performance in giving effect to committee views under the optional protocol.

A key weakness of the committee is the limitation on the ability of the Committee to enforce remedies. The domestic courts often ignored the committee interpretation of the covenant, even in cases where international laws are directly incorporated in their domestic laws. It means that state parties are ignoring the jurisprudence of the committee. For example the annual report of 2000 says that Austria is still maintaining the rule of discriminatory pension measures, despite committee views in Pauger (716/1996). But the situation is not as bad as after Broek, the Dutch government admitted that there should be equality in social security systems. So, there are certain signs of progress.

\section{The European Convention on Human Rights}

Article 14 of the convention deals with discrimination. This article does not promote right to equality. Under this convention, even direct discriminations are also lawful, if they are justified. The scope of this article is limited to only substantive rights mentioned in the convention. Article 14, states that,

The enjoyment of the rights and freedoms set forth in this Convention shall be secured without discrimination on any ground such as sex, race, colour, language, religion, political or other opinion, national or social origin, association with a national minority, property, birth or other status.

The phrase "shall be secured creates" positive obligations on states to protect its citizens against discrimination but the extent of this obligation is not clear. The European Court of Justice in Belgian Linguistics case (1968 1 EHRR 252), defines that only those distinctions are discriminatory that have

- No objective and reasonable justification.

- Not in pursuance of legitimate aim.

- No reasonable relationship of proportionality between the means employed and the aims that has to be realized [1].

Article 14 does not promise autonomous right to equality. To invoke article 14 , it is necessary that the claim of the claimant fall within the ambit of the convention substantive rights. For instance in Abdulaziz,
Cabales and Balkandali v the UK (1985) 7 EHRR 471, complainant's claim succeeded because their discriminatory treatment fell within the ambit of article 8.If substantive rights would not have been involved then any discriminatory argument would fail.

It is not clear, even after finding violation of a substantive right, from Strasbourg case laws that when court will examine Article 14. For instance in Sheffield and Horsham v UK (1998 26 EHRR 241) the applicant argued breach of right to respect for private life (Article 8), as transsexuals (applicants) failed to amend their birth certificates. The court held that article 8 was not violated by narrow margin of 11 votes out of 9 , and at the same time rejecting claim under article 14 unanimously.

Moreover, when there is breach of any substantive right along with an allegation of discriminatory treatment it is not clear from the court that whether it would examine that there is any breach of Article 14 or not? (Dudgeon v UK 19814 EHRR 419).

The court interpreted article 14 as requiring an 'analogous situation' test. For instance in Van der mussel v Belgium, (1983, 6 EHRR 163) the court held that there is no violation of article 4 (protects against forced labour), but the Article 14 complaint (barristers require to work certain numbers of hours of pro bono work, while other professionals do not) fell within the ambit of article 4. However, application failed because court found that court is under no obligation to justify this differential treatment as there are fundamental differences between the ways in which every professional works.

From Strasbourg case laws it is clear that some ground of discrimination required more scrutiny. Discrimination on ground of sex, race and illegitimacy is treated as "suspect class" by the court (Marckx v Belgium series A 31 (1979) 2 EHRR 330).

Sometimes court applied the doctrine of margin of appreciation, although this doctrine has been exposed to criticism (Ramussen $\mathrm{v}$ Denmark 1984 series A 87, 7 EHRR 371).

In Strasbourg institutions the concept of indirect discrimination has not been fully developed (Schuler-Zraggen $\mathrm{v}$ Switzerland, series A 1993, 16 ECHR 405).

In Vienna submit (1993) it was agreed that awareness raising campaign against all forms of discrimination is launched throughout Europe. An expert body called; the European Commission against Racism and Intolerance (ECRI) was also created, one of the tasks given to commission is to examine international human rights instruments to remove weaknesses from Art 14 and submit its report to Committee of Ministers. ECRI drew attention that clause 14 has no independent existence and its protection does not cover the rights not mentioned in the convention. According to ECRI, because of accessory nature of Article 14, Strasbourg case laws on racial discrimination are weak. ECRI recommended that this protection to discrimination can be strengthened by an additional protocol containing general clause against discrimination. ECRI proposed some proposals.

The Steering committee for equality between man and woman (CDEG) also points out weakness in article 14, that it does not provide legal protection to right of man and woman to equality as autonomous fundamental right. ECHR does not recognize the right of woman and man to equality; therefore there is no protection against discrimination on the grounds of sex in the application of rights not mentioned in the Convention. The CDEG argues that discrimination on the grounds of sex are dealt on separate footings as sex is structural order, while all other (race, colour, origin, language, political) are gendered based. To 
Page 5 of 5

eradicate inequalities on the ground of sex there should be an abstract equality between genders. On the basis of this approach CDEG proposed some proposals. The $\mathrm{CDDH}$ had difficulty in accepting proposals, because they are not ready to treat gender based discrimination separately in distinct additional protocol to ECHR.

Finally, CDDH proposed following wordings of protocol 12 to strengthen ECHR.

The enjoyment of any right set forth by law shall be secured without discrimination on any ground such as sex, race, colour, language, religion, political or other opinion, national or social origin, association with a national minority, property, birth or other status. No one shall be discriminated against by any public authority on any ground such as those mentioned in first sentence of this provision.

This protocol has tried to strengthen the ECHR in areas of equality and non-discrimination, where it is notoriously weak. Protocol 12 will come into force when it was ratified by ten member states. The United Kingdom has not signed the protocol because government think this protocol is' too general and open ended', the coverage of 'rights set forth' in law is very wide and new rights are also not cost free [3]. Such objections are rejected as 'misconceived' and 'unconvincing.'

Choudhury argues that provisions of protocol 12 appear to match with the United Kingdom's existing obligations under Art 26 of ICCPR. By signing protocol 12 United Kingdom could perform its preexisting obligations in international law effectively.

It might be agreed upon because when we read both provisions (protocol 12 and Art 26) side by side, it becomes quite clear that obligation arising out of these provisions is quite same. The domestic and European courts supervision will provide effective remedies when government is in breach of its obligations [4-6].

\section{Conclusion}

Human rights are based on humanity. But, most of human rights instruments allow the distinction based on nationality. For instance CERD, Charter of fundamental rights. The Charter contains two sets of rights, one for everyone and other set of rights is reserved for E.U nationals. According to Art 1 of UDHR, "All human beings are born free and equal in dignity and rights". Few basic flaws in these instruments should be removed so that discrimination on any ground should be eradicated. The need is to set aside this distinction and let every individual enjoy all human rights [5]. The fight against Racism should be fought at every level from top to bottom, because it affects society at every level. Right to equality is a fundamental human right and the availability of this right to everyone should be made possible at any cost. Discriminatory attitudes and racist violence do not allow countries to progress. Effective implementation of human right instruments is necessary to eradicate discrimination.

Like America and Canada, the need is to have "twin track approach" against discrimination i.e. both constitutional and statutory levels. UK is lacking in this approach, although they claim "to bring home" rights in form Human Rights Act 1998, but the inevitable weakness of Art 14 has not been removed yet, as the UK has not signed protocol 12 .

One would agree with CRE chair Trevor Phillips who said that: "The fact that we have strong anti-discrimination laws has led to the near disappearance of commonplace practices which disfigured our society. That does not mean they don't ever happen but today they are the exception rather than the rule".

Thus, a lot more work is needed to be done in developing countries as this evil has affected them most. The thing that is lacking in all human right instruments is the ability to enforce effective remedies when states are in breach of its obligations. Likewise, the problem of indirect discrimination should be handled with iron hands not to let the evil to grow. The need is to eliminate the root causes that are promoting discrimination. This can be done by educating the masses, by inculcating a sense of responsibility among them, and by reassuring the equality in society through laws.

\section{References}

1. Moon G (2000) Race discrimination, developing and using new legal frame work. Oxford, hart.

2. McColgan A (2003) Principles of equality and protection from discrimination in international human rights law. E.H.R.L.R 2: 157-175.

3. Choudhury $\mathrm{T}$ (2003) Interpreting the right to equality under Article 26 of the International Covenant on Civil and Political Rights. E.H.R.L.R 1: 24-52.

4. John C (2005) Four decades of UK race law. BBC News community.

5. JamesNickel (2006) Human Rights.

6. Vernellia RR (1997) Race, Racism and the Law, speaking truth to power. 